\title{
Medtronic社製Bio Trendの監床使用経験
}

\section{久保田好光}

\begin{abstract}
要旨

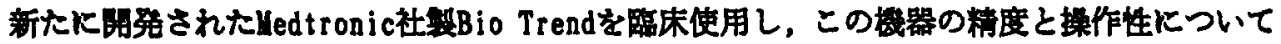

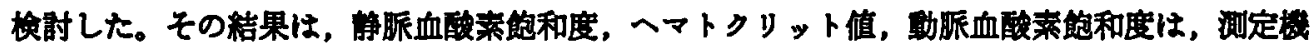
器との間に高い相関関保が見られた。また，整正しない值です，厚めて高い相闺を認めた。

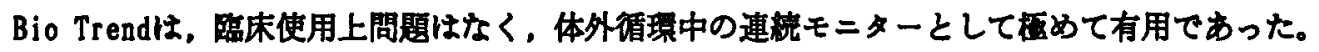

Key words: Bio Trend, $\mathrm{SaO}_{2}$, Hct 值, $\mathrm{SvO}_{2}$

\section{I .はじめに}

現在，体外偱渨中の混合諍脈酸素飽和度(以下， $\mathrm{SvO}_{2}$ )，ヘマトクリット值(以下, Hct值)，野脈血酸

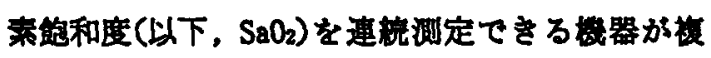
数のメーカーより市服されている。今回我々は， 連䊑的に $\mathrm{SaO}_{2}, \mathrm{SvO}_{2}$ ，およびHct值を連繶モニター

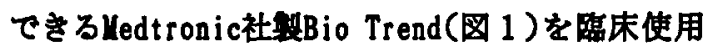

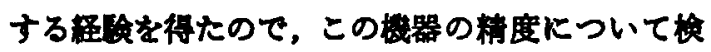
討するととるに，操作性についてる検討した。

\section{II . 対家および方法}

対象は当院で行われた成人開心術症例40例を対 象とした。

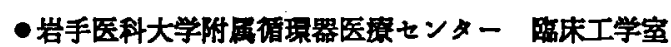

衰 1 対争および方法

\begin{tabular}{|c|c|}
\hline \multicolumn{2}{|c|}{ 対魚：体外活理を行った成人閒心街症例：40例 } \\
\hline (探血) & （睌定项目） \\
\hline - ECC10分 (枝正) & - $\mathrm{SaO}_{2}$ \\
\hline 冷却時 & - $\mathrm{Sv}_{2}$ \\
\hline - ECC20分 & - Hctî \\
\hline - ECC45分 & (測定幾器) \\
\hline 復温時 & 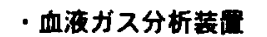 \\
\hline - 加温10分 & Ciba Corning 288 \\
\hline - 加温20分 & 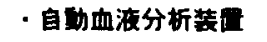 \\
\hline & テクニコン H-3RTX \\
\hline
\end{tabular}

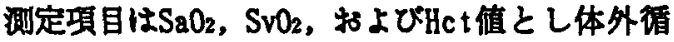
謤開始後10分の测定值にて较正を行い，その後20 分，45分を冷却時，加温開始後10分，20分を復温時 として検体を採取した。同様に，全く较正を行わ ないものとも比較㭘討した(表 1 )。 $\mathrm{SaO}_{2}, \mathrm{SvO}_{2}$ につ

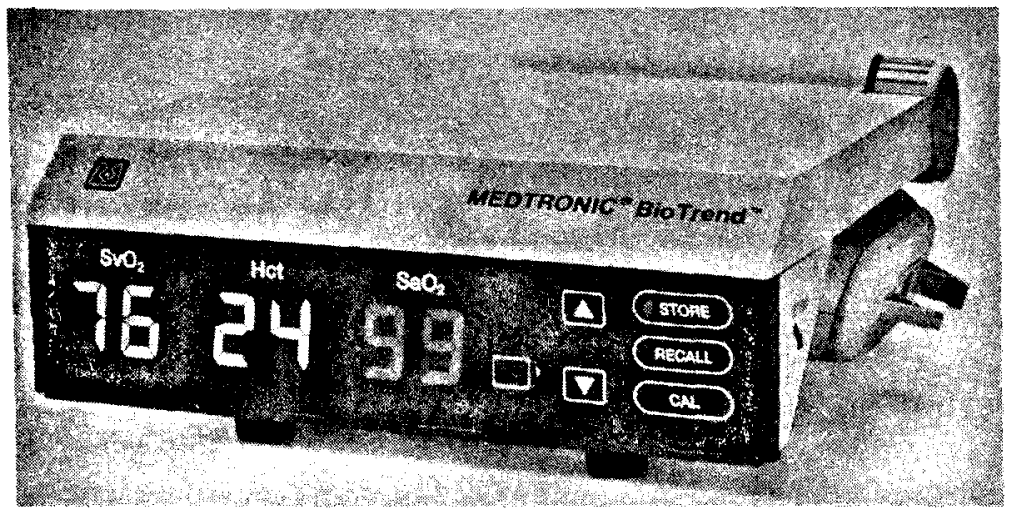

国 1 Bio Trend 
いては，測定装置との回帰直線および相関係数を 求め,Hct値については,検体検查值との回帰直線特 よび相関係数を求めた。な拉，検体検查には測定 機器として，血液ガス分析装置Ciba Corning288と 自動血液分析装置バイエル社製テクニコンH-3RTX を使用した。

\section{III. 結 果}

$\mathrm{SaO}_{2}$ の回帰直線括よび相関係数は, 冷却時: $y$ $=0.11 \mathrm{x}+89.13, \mathrm{R}=0.79$, 復温時: $\mathrm{y}=0.27 \mathrm{x}$

\section{表 2 比較表}

\begin{tabular}{|c|c|}
\hline 较 正 あり & 較正なし \\
\hline $\begin{array}{l}\cdot \mathrm{SvO}_{2} \\
\mathrm{C}: y=0.89 x+9.99(R=0.96)\end{array}$ & $\begin{array}{l}\cdot \mathrm{Sin} \mathrm{O}_{2} \\
\mathrm{C}: \mathrm{y}=0.99 x+1.15(\mathrm{R}=0.98)\end{array}$ \\
\hline$H: y=0.93 x+4.83(R=0.90)$ & $H: y=1.09 x-7.28 \quad(R=0.97)$ \\
\hline - Hct & - Hct \\
\hline$C: y=1.08 x-1.05 \quad(R=0.98)$ & $C: y=1.07 x-1.49(R=0.99)$ \\
\hline$H: y=0.93 x+2.29(R=0.94)$ & $H: y=0.90 \times 3.45 \quad(R=0.96)$ \\
\hline $\begin{array}{l}\cdot \mathrm{SaO}_{2} \\
\mathrm{C}: \mathrm{y}=0.11 x+89.1(R=0.79)\end{array}$ & $\begin{array}{l}\cdot \mathrm{SaO}_{2} \\
\mathrm{C}: \mathrm{y}=0.12 x+87.8(R=0.85)\end{array}$ \\
\hline$H: y=0.27 x+73.0(R=0.73)$ & $H: y=0.11 x+89.0(R=0.83)$ \\
\hline
\end{tabular}

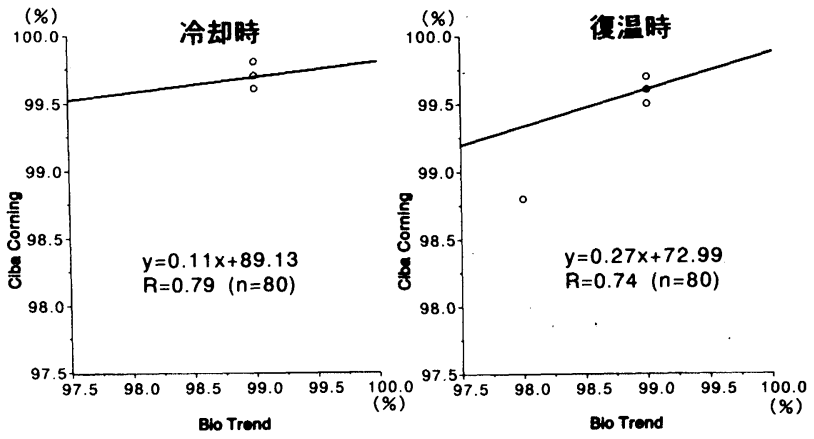

図 $2 \mathrm{SaO}_{2}$ の回帰直線と相関係数

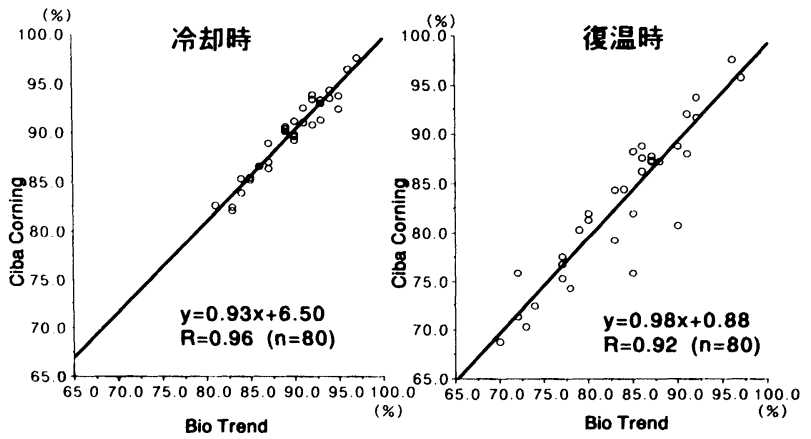

図 $3 \mathrm{SvO}_{2}$ の回帰直線と相関係数

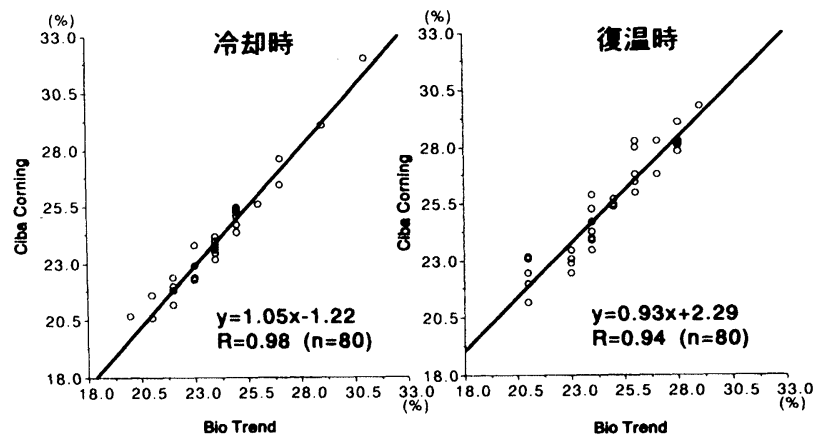

図 4 Hct 值の回帰直線之相関係数 
$+72.99, \mathrm{R}=0.74$ であった(図 2)。

$\mathrm{SvO}_{2}$ の回帰直線扣よび相関係数は, 冷却時: y $=0.93 \mathrm{x}+6.50, \mathrm{R}=0.96$ と, 復温時: $\mathrm{y}=0.983$ $\mathrm{x}+0.88, R=0.92$ であった(因 3 )。

Hct值の回帰直線括よび相関係数は, 冷却時：y $=1.05 \mathrm{x}-1.22, \mathrm{R}=0.98$ と, 復温時: $\mathrm{y}=0.93$ $\mathrm{x}+2.29, \mathrm{R}=0.94$ であった(図 4 )。

また，体外循環開始後10分の測定値にて較正を 行った群と較正を行わなかった群との比較を表 2 に示す。全ての項目について，較正なしの群にお。 いて高い相関関係を示し, 較正ありの群との有意 差はなかった。両群とも $\mathrm{SaO}_{2}, \mathrm{SvO}_{2}$ は血液ガスの変 動が大きい冷却時と復温時に高い相関が得られ た。同様にHct值についても高い相関関係を示し た。

\section{N. 考 察}

Bio Trendは連続的に $\mathrm{SaO}_{2} ， \mathrm{SvO}_{2}$ ， $\mathrm{Hct}$ 值を連続測 定することができ，これにより，体外循環開始時
に怙ける人工肺の酸素化不良の判断，心筋保蓄液 などによる過度の血液希釈，および，復温時の酸 素供給不足などに迅速に対応でさると考えられ た。また，BioTrendは使用前にキャリブレーショ ンが必要であるが，それに要する時間は約20秒と 短時間で，使用中の較正をしなくてもHct值を表示 するので，非常に簡単にモニタリングできた。

以上のことから，緊急手術など迅速な準備が要 求される時など，BioTrendの使用は，体外循環中 のモニターとして有用であると考えられた。

\section{V ．まとめ}

(1) $\mathrm{SaO}_{2}, \mathrm{SvO}_{2}, \mathrm{Hct}$ 值は測定装置と検体検查值と の間で極めて高い相関を示した。

(2) 較正なしの值でも極めて高い相関関係を示し た。

(3) Bio Trendは体外循環中のモニターとして良好 な結果を示し活用できると考光られた。 